\title{
VISUAL DOCUMENTATION OF THE STATE OF CONSERVATION BY MEANS OF UAV: THE CASE OF MARBLE CLADDING SYSTEM ON THE FAÇADES OF THE BRAZILIAN PALACE OF CONGRESS
}

\author{
BRUNA BARBOSA LIMA \& VANDA ALICE GARCIA ZANONI \\ Faculdade de Arquitetura e Urbanismo, Universidade de Brasília, Brazil
}

\begin{abstract}
The high-rise building appeared as a constructive tendency in the 20th century. It also stood out in this period the researches for new materials and traditional materials applied in innovative ways. The stone, for example, began to be adopted as slabs, as part of cladding systems in modern buildings façades. This shift has raised the question of how to conserve this material as part of façade systems, a subject underexplored in the Conservation Technology field. Moreover, there are difficulties imposed to the inspection and monitoring of high-rise buildings façades. In this context, it is proposed to investigate the conservation of stone cladding systems, its characteristics, behaviour and cause and effect relations that affect its ageing. For that, it is adopted as case study the Brazilian Palace of Congress, specifically its 28 -story towers. Conceived in the 1960 s to be the highest building in the capital, it presents the white marble as one of the elements that confer unity in the modern set of the Palaces of Brasilia. In order to characterize the object of study and its state of conservation, the damages were mapped according to the procedures: i) capture of images by means of a digital camera conducted by Unmanned Aerial Vehicle (UAV); ii) digital processing with generation of orthomosaics; and, iii) damage vectoring. Despite the obstacles during the capture of images, such as adverse climatic conditions and the inherent characteristics of marble slabs (white and highly reflective surface, natural pattern easily mistaken with pathological manifestations), the procedures were effective in meeting the proposed objectives. Finally, the information obtained will be used in the subsequent stages of analysis and intervention proposal, as intended to contribute to the conservation actions regarding the marble cladding system, and the safeguarding of this remarkable example of modern heritage.

Keywords: modern architecture, high-rise buildings, façade systems, marble cladding systems, estate of conservation, UAV, Brazilian Palace of Congress.
\end{abstract}

\section{INTRODUCTION}

The high-rise building was consolidated as a constructive trend in the 20th century, driven by advances in the calculation of structures and foundations, the invention of the elevator and the development of building materials such as steel and reinforced concrete [1]. In the scope of the researches with materials, stands out the shift in the way of using stones at constructions. From the prevailing use as blocks in walls, columns, foundations and arches, with the evolution of the techniques of anchoring and processing, it began the adoption of the slender slabs of stone integrating cladding systems on large façade surfaces.

In the Brazilian case, stands out the fundamental role of the stone cladding systems in the expression of the Palaces of Brasilia [2]. In this unique context, the marble gives the white of prominence and, at the same time, cohesion of the buildings in the landscape of the Esplanade and civic square.

The studies on stone conservation focused on the material are predominant in the Conservation Technology field, which leads to inconsistent diagnoses when considered the system as a whole. Due to the relevance of stone cladding systems in the 20th century architecture and the lack of a full understanding of the degradation processes, it is urgent to investigate methods and procedures aimed to their conservation. 
In this context, the objective of this article is to present a method of analysis to support the investigation of the state of conservation of marble cladding systems in modern architecture, particularly the typology of high-rise buildings. Specifically, the paper will present the physical survey stage through Unmanned Aerial Vehicle (UAV), photogrammetry and prospectings. The proposed procedures aim to survey the characterization and the state of conservation of the studied system, including the dimensions and functions of each layer.

In order to test the developed method, it was chosen the marble cladding system of a notable example of modern architecture: the Brazilian Palace of Congress. The white marble installed in the gables of the twin towers, created to be the highest ones in the capital [3], has great relevance in the context of the construction of Brasilia. However, there is a lack of detailed information on the physical (technical and constructive) aspects of the system, the conditions of use and exposure and its state of conservation, in order to base future actions of conservation and maintenance.

It is expected a contribution to the repertoire of inspection and analysis techniques in high-rise buildings by means of UAV and photogrammetry, in order to monitor, in the scope of preventive maintenance, the stone cladding system of the object of study - with the possibility of transposition to similar cases.

\section{THEORETICAL FRAMEWORK}

In view of the relevance of stone in modern architecture, further study on how to conserve this material as part of a façade cladding system is necessary. Several researches such as Oliveira [4], Frascá [5], Haas [6] and Aires-Barros [7] approach the theme from the perspective of the chemical processes of alteration in stone material, with emphasis on the stone blocks instead of the stone used in coating.

As for the methods and techniques of high-building's façade inspection, the difficulty in accessing some areas is one of the challenges imposed to the realization of the necessary surveys. In these cases, the UAVs are an alternative considered promising [8], [9].

The use of this tool in the field of Architecture and Engineering has been the subject of several studies, as it can be adopted to manage construction works, to inspect façades and to survey and measure architectural elements. Regarding the studies about its application as a support to the damage mapping, we highlight Melo Júnior [8] and Córdoba [10], who associate the technique with short-distance photogrammetry; Tondelo and Barth [9], who analyse constructive aspects and pathological manifestations of industrialized façades; Kim et al. [11], who adopt the digital processing of the images obtained for the identification of cracks in concrete structures; and Ham et al. [12], who present a bibliographical review of the most recent inspection methods adopting UAV.

In the photographic survey, the images generated to produce damage maps must have pixel size (PS) according to the level of precision required. For digital cameras, the resolution depends on the number of pixels, the size of the digital sensor, the distance to the object and the focal length [8]. In addition, the camera parameters that influence the image accuracy (focal length, aperture, exposure time and ISO sensitivity) must be set to the local conditions.

The distance between the camera and the building should be as minimal as possible, once assured the safety requirements related to the equipment and, especially, the built heritage. Tondelo and Barth [9] established this distance in $80 \mathrm{~cm}$ for an analysis of a building envelope with only three floors, and Melo Júnior [8] recommends 3 meters and suggests the prior calculation of the distance between photographic takes.

Once the images have been obtained, they must be prepared for damage identification phase. In the field of Computer Science, the area of Computer Vision studies the methods for 
the automated extraction of information from images, with emphasis on digital photogrammetry, specifically Dense Stereo Matching (DSM) [8].

Groetelaars [13] classifies DSM as the latest evolution of the automated photogrammetric techniques to obtain geometric models, based on the automatic correlation of sets of homologous pixels in different photos for the generation of the so-called "point cloud" orthoimages, that is, two-dimensional products obtained by the orthographic projection of the geometric models.

Another line of study in the Computer Vision is based on techniques of automatic extraction of characteristics or attributes of an object. In this context, Melo Júnior [8] investigates the extraction of information on pathological manifestations in façades through digital image processing, while Costa and Amorim [14] applied a methodology for mapping damages from digital photogrammetry. The actors conclude that the use of orthoimages for the production of damage maps gave more speed and rationality to the work, although it did not dispense the complementary surveying such as prospectings and laboratory tests.

\section{PROPOSED METHOD}

The method of analysis of the state of conservation for marble cladding systems was developed by means of bibliographic review on the topics of stone conservation - including existing conventions to identify damages such as IPHAN [15], ICOMOS-ICS [16], UNI 11182 [17], and NORMAL 1/88 [18] - methodologies of risk analysis as BS EN 60812 [19] and building monitoring and inspecting as in ASCE [20], ASTM [21], Cóias [22], Tinoco [23] and Lichtenstein [24]. The proposed method is divided into three stages:

1. Surveying, which includes procedures for the identification and characterization of the object of study and its state of conservation, by means of research on the history of the building and physical surveying;

2. Analysis of the state of conservation, with identification of failure modes, their causes and effects, the Stress Zones and prioritization of damages; and,

3. Elaboration of the conservation scenarios, which include the historical representative scenarios, in the present condition and as future trends of the state of conservation of the system under study.

This paper emphasises the surveying phase, more specifically the physical surveying by means of UAV, digital photogrammetry and prospectings, as detailed below.

\subsection{Survey of data}

The objective of the surveying phase was to collect the necessary information for the technical characterization and the state of conservation of the studied system, including its components and layers, its dimensions and functions, according to the recommendations of the BS EN 60812 [19]. For this purpose, procedures were adopted for the research on the building history and for the survey of physical aspects and state of conservation. The history survey is based on the anamnesis procedures, that is, the observation process of the building timeline in order to understand the damages [23]. This step aims to obtain information about the marble cladding system state of conservation by surveying its historical narrative as part of the building, from the construction activities to the interventions undergone.

The physical surveying, on the other hand, is the research for the current situation of the studied system by combining the following methods and techniques: the capture of images using UAV, the generation of orthoimages of the façades by means of digital photogrammetry, and damage vectorization per CAD (Computer Aided Design) tool. The 
phase starts from a preliminary surveying (general inspection) by the means of visual analysis and photographic records, which provides recognition of the façade's typology, the general aspects of the system, the exposure conditions and the damages of easy detection, in order to enable the planning and definition of the approach to the next phases [21]. In this sense, procedures such as laboratory tests and prospectings can contribute to the collection of data for evaluation, analysis and recommendations [20].

The inspection of façade systems in the high-rise building typology adds the difficulty of access all sections of the façade, which is why the UAV is adopted to capture images. The photographs obtained, besides the damage mapping support, consist of photographic documentation for recording the current state of the study object.

Flight planning for image capture should be based on the purpose of the surveying, the type of processing and the accuracy expected, and involves the equipment selection, the analysis of the surroundings, the definition of day and time with favourable conditions to flight and photographic takes, the definition of the camera distance to the building, and the determination of the images overlap and the distance between the photo shoots as well. From the photographs obtained, the models are generated by DSM. The orthoimages of façades, the digital processing products, support the consolidation of the physical surveying of the building, specifically the façade system studied, and the production of damage maps.

In the sequence, the pathological manifestations and interferences in the system are represented graphically by means of vectorization in CAD tool. The identification is based on pre-established concepts and graphic conventions. Finally, in situ prospectings is foreseen to obtain detailed information for the characterization of the system.

The physical surveying obeys a sequence of steps, according to the flowchart in Fig. 1.

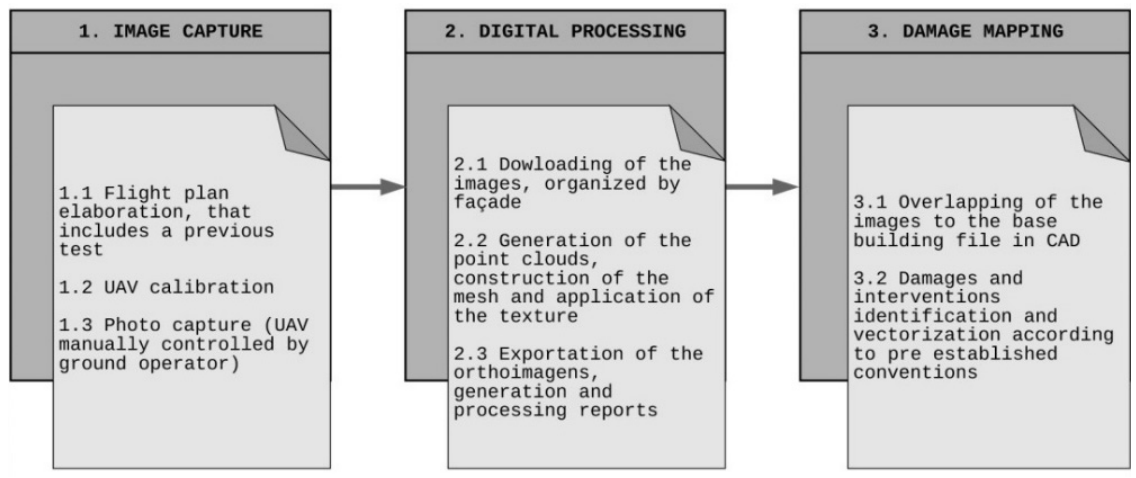

Figure 1: Flow chart of the physical surveying phase. (Source: Author, 2019.)

\section{PRESENTATION AND DISCUSSION OF RESULTS}

In order to test the method, the Brazilian Palace of Congress was chosen as the case study, specifically the white marble cladding system in the gables of the towers, within the thematic focus proposed.

\subsection{Case study: the marble cladding façades of the Brazilian Palace of Congress}

The Brazilian Palace of Congress is the set of the horizontal block, the Main Building or "Edifício Principal" - which supports the domes that mark the plenary of the legislative houses - and the two towers that are a vertical landmark on the horizon. The white marble 
installed on the tower gables is a typical element of the niemeyerian expression in the context of the monumental Brasilia conception. The 28-storey towers in steel and concrete structure, with Northwest and Southeast solar orientation, have gables of $980 \mathrm{~m}^{2}$ coated with marble.

The façade system consists of a coating layer of polished white marble slabs (approx. $40 \mathrm{~cm} \times 81.5 \mathrm{~cm}$.), with fixing pattern defined by the slabs joints (approx. $2.3 \mathrm{~mm}$ thick), vertically interleaved and horizontally aligned. The gables also have horizontal joints of movement of about $21 \mathrm{~mm}$.

For methodological purposes, the façade panels of $10.35 \mathrm{~m} \times 3.25 \mathrm{~m}$ delimited by the movement joints of each pavement configure the regions to be investigated and analysed in the application of the method, adding up to 30 regions per gable. It is important to notice that the dimensions of regions and slabs vary on the basement and top areas of the towers. There is also a variation on the edges of the façades with curtainwalls (southwest and northeast) of both towers, where the marble slabs have about $27 \mathrm{~cm}$ of width. In the sequence, there are the results for the studied object according to the sub-steps of image capture, digital processing and prospectings.

\subsection{Image capture with UAV}

The photographic surveying procedures were carried out, starting in December 2018, at South tower's gables of the Brazilian Palace of Congress. The North tower was not included due to restrictions imposed by the department responsible for its administration (intervention services on the façades were in progress, in the scope of Public Notice 036/2017 [25]).

At that time, the UAV DJI Phantom 3 Pro was used, but the images obtained did not meet the quality required to identify the damages in the system, which led to new surveying with the DJI Phantom 4 Pro, equipped with built-in digital camera. The camera's technical specifications, coupled with greater flight stability, have resulted in significant improvement in the photos quality. The characteristics of the cameras are compared in Table 1.

Table 1: Technical specifications of the cameras. (Source: Author, 2019.)

\begin{tabular}{|l|c|c|}
\hline Parameters/equipment & DJI Phantom 3 Pro & DJI Phantom 4 Pro \\
\hline Maximum pixel resolution (píxel) & $4,000 \times 3,000$ & $5,472 \times 3,648$ \\
\hline Effective megapixels (MP) & 12.4 & 20 \\
\hline Sensor (mm) & 11.04 & 25.4 \\
\hline Opening angle & $94^{\circ}$ & $84^{\circ}$ \\
\hline Focal length (mm) & 20 & 24 \\
\hline
\end{tabular}

In January 2019, the image capture procedures began with a test conducted on the first region of the Northwest gable. It started at 3:00 p.m. in Brasília summer time, with clear, cloudless sky. The camera was set to shutter speed 1/800s, aperture f/6.3 and ISO 100. Since the images met the requirements, the surveying started on the following day, taking two days due to the need of adjusting the photographic parameters of the camera to the environmental conditions.

On the first day of the image capture phase through UAV, the services started at 7:40 am, in a cloudy day with prevailing winds from the Southeast. The camera settings were shutter speed 1/640s, aperture f/6.3 and ISO 500. The surveying of both façades lasted about 18 minutes each and obeyed the flight plan detailed in Fig. 2. Although the cloudiness provides a homogenous illumination, the obtained images lost sharpness in comparison to those of the test phase. 

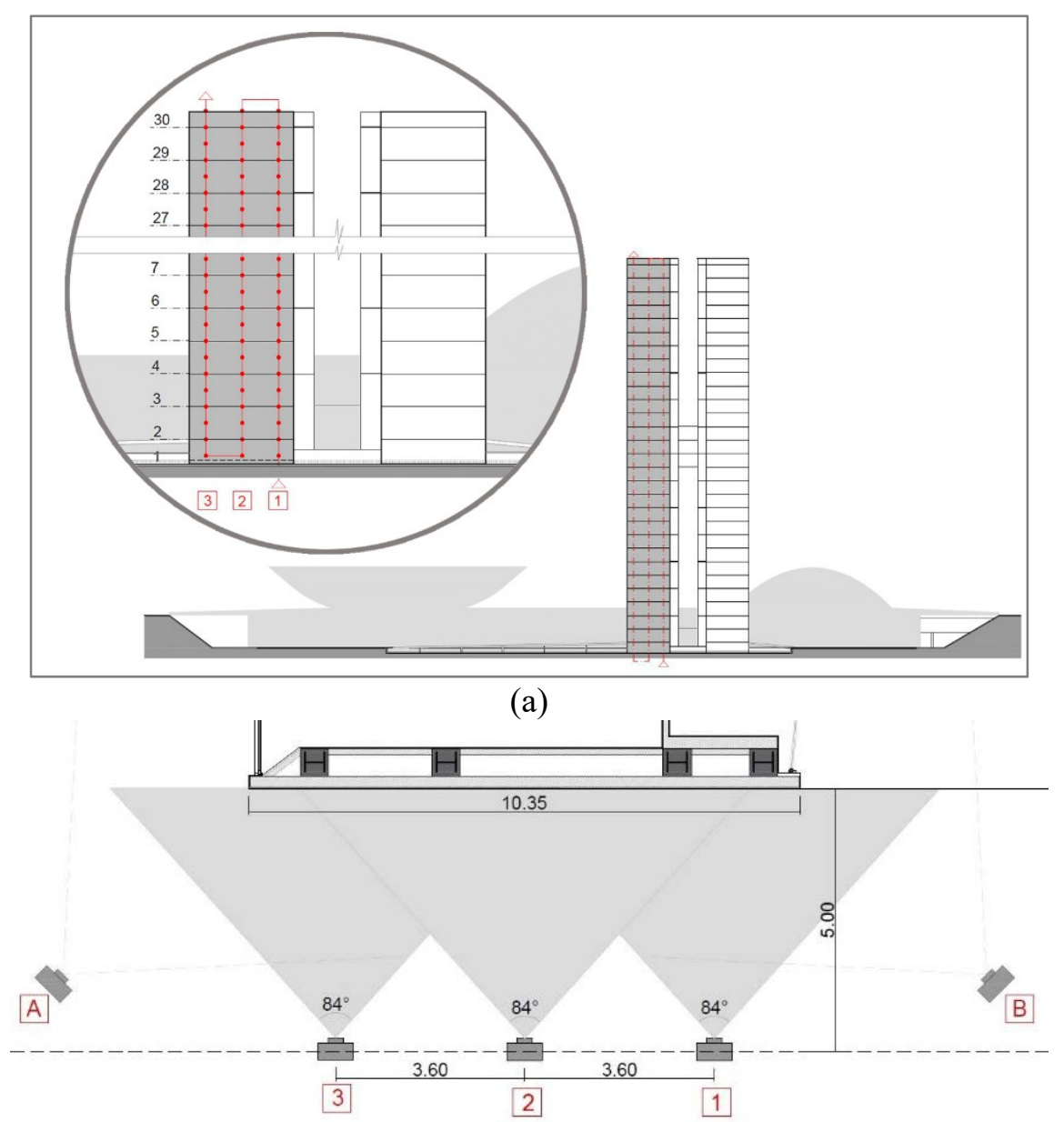

(b)

Figure 2: Flight plan for the south tower, southeast gable. (a) Elevation showing the flight lines; (b) Plant with the distances established for the photographic takes. (Source: Author, 2019.)

In this sense, the procedures were repeated in a more propitious day. At the scheduled date, the environmental conditions were like the day of the test: clear sky and sun at the centre of the celestial dome (due to the start time, 13:00 Brasília summertime), with strong winds from South and Southeast. The camera settings were: $1 / 1000$ s shutter speed, f/7.1 aperture and ISO 100. The photographic takes lasted about 20 minutes for each gable, and the strong air currents made it difficult to stabilize the aircraft but did not prevent the capture of images.

Regarding the planning, the distance between the aircraft and the building was defined in five meters, balancing the safety requirements and the quality of the images. The overlap established for the photographs was $60 \%$ laterally and $80 \%$ longitudinally. The distance between the flight lines ensured lateral overlap, and to achieve the longitudinal overlap, it 
was necessary to balance the flight speed and shooting frequency of the camera, performed manually by remote control, along with visual verification by means of auxiliary screen.

Thus, the capture of images was carried out in three flight lines $3.60 \mathrm{~m}$ apart from each other - the first one was taken with the UAV going up, the second one with the aircraft going down and a final one going up again. In each flight line, photos were taken two points per region, one aligned with the movement joint and the other at half the height of the region, in other words, at the equidistant point between two joints (Fig. 2(a)).

The distance $(B)$ of $3.60 \mathrm{~m}$ between the flight lines was obtained as a function of the camera's opening angle $\left(84^{\circ}\right)$, the percentage of overlap defined $(60 \%)$ and the distance of the camera related to the façade (5), according to eqn (1), based in Melo Júnior [5]

$$
B=2 \tan \frac{84^{\circ}}{2} 5 .\left(1-\frac{60 \%}{100}\right) \text {. }
$$

In addition to the flight lines perpendicular to the façade, photos were taken of the edges, since these parts also integrate the system and can contribute to understand its behaviour and degradation processes. It was decided to register the edges at a $45^{\circ}$ angle, since a perpendicular capture would not be possible due to the restrictions offered to the UAV access in the air space between the two towers, such as possible system failures and destabilization of the aircraft due to the strong winds. These photographic points are represented in Fig. 2(b) as "A" and "B". Fig. 2(b) also shows the distances established in plant for the UAV in relation to the façade and between the photographic takes.

During the surveying, there was a difficulty in keeping the camera distance from the façade. Despite the parameters defined in the planning, there was a variation, common in inspections in high-rise buildings with use of UAV in manual (non-automated) flight due to air currents and lack of pilot reference points on the higher floors. As a measure to try to reduce these variations, photos were taken by a team consisting of a pilot and an observer equipped with an auxiliary screen for visual verification of the UAV position.

Another challenge in obtaining images with adequate resolution was the configuration of the camera photographic parameters because of the inherent characteristics of the marble coating, such as its white colour and the highly reflective surface. This difficulty motivated the flight test and the repetition of photo takes activities.

The images were then filed in the JPEG and DNG extension, and the compressed files (.jpg) adopted in the processing.

\subsection{Point Cloud Processing (DSM)}

After obtaining the photographs, they were downloaded and filed on the computer accordingly to the façade. The next phase was the point cloud image processing, by means of the Agisoft's PhotoScan Professional version 1.4.2 software. The steps for orthoimages generation were the following: alignment of images, reconstruction of the sparse cloud of points, construction of dense cloud of dots, construction of the mesh, and texture application.

The reports produced showed the variation of UAV distance in relation to the plane photographed: the average distance was $6.85 \mathrm{~m}$ for the Southeast gable and $7.03 \mathrm{~m}$ for the Northwest. It is also reported that the PS obtained were $1.73 \mathrm{~mm} / \mathrm{pixel}$ and $1.81 \mathrm{~mm} / \mathrm{pixel}$, respectively. The PS analysis allows concluding that the obtained images did not present the ideal detail level for the identification of fissures equal to or less than $0.5 \mathrm{~mm}$, or even cracks between $0.5 \mathrm{~mm}$ and $1 \mathrm{~mm}$. The factors that influenced these results were the restriction of UAV proximity relating to the façade (for security reasons, as already explained) and the digital camera adopted. Although shooting at $20 \mathrm{MP}$, the built-in camera has a sensor that 
produces lower resolution images when compared to other digital cameras. The original camera was maintained, however, because the adaptation of the aircraft with other photography equipment would interfere in the weight of the set, possible affecting its stabilization during the flight and the photographic takes. Furthermore, it would implicate problems related to the flight permission.

The orthoimages exported in the TIFF format were then inserted into the Autodesk CAD platform, Autocad software version 2017, allowing the updating and complementation of the physical surveying of the building, as well as the identification and graphic registration, by means of vectors, of the pathological manifestations visible in the marble cladding system.

\subsection{Prospectings}

In order to obtain additional information for technical characterization of the studied system, prospectings were carried out on external and internal points of the gables, due to the configuration of the building envelop as a double wall system. The prospectings showed that the marble cladding system consists of a $30 \mathrm{~mm}$ thick polished white marble slab (approx. $40 \mathrm{~cm} \times 81.5 \mathrm{~cm}$ ) fixed on mortar, substrate and masonry of ceramic bricks.

A prospecting on the outer wall of the Southeast gable showed the presence of $20 \mathrm{~mm}$ marble slabs and 1/8 galvanized steel fixation wires at the back of the slabs. Petrographic tests carried out on samples of stone from this area suggested that they are interventions subsequent to the building construction, and interviews conducted with the teams responsible for building maintenance corroborate this hypothesis.

The internal prospecting of the Northwest façade confirmed the existence of double walls, according to the original designs. The outer wall, the support of the façade cladding system, is made of 6-hole ceramic bricks and dimensions of $14 \mathrm{~cm} \times 19 \mathrm{~cm} \times 9 \mathrm{~cm}$ of light brown colour, which probably indicates a brick of high burning and greater resistance. The masonry type of seating observed is very common in external vertical wall systems due to resistance and water tightness improving. The internal masonry, in its turn, has 8-hole clay red ceramic bricks of $19 \mathrm{~cm} \times 19 \mathrm{~cm} \times 9 \mathrm{~cm}$ (Figs 3 and 4). It is also possible to observe at Fig. 3 the pillar of concrete and steel located between the double walls.

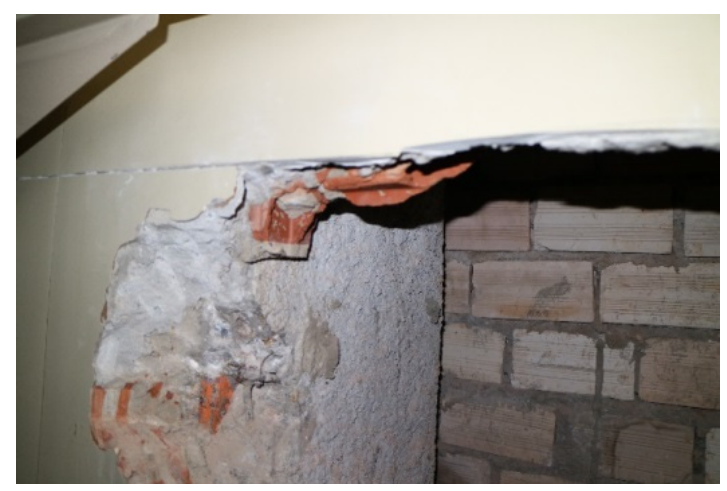

Figure 3: Prospecting at the south tower, northwest gable. (Source: Author, 2018.)

The internal melamine phenolic laminate coating was installed in the 1980s, when the South tower was submitted to a series of interventions aimed at meeting fire safety regulations. The renovation included the replacement of mobile partitions and internal 
coatings, the recovery of the curtainwalls of Southwest and Northeast façades, the installation of helipad in the roof and the revision of the electrical, hydraulic, telephone, audio, air conditioning and sprinkler installation [22]. Possibly, the internal wall was redone on that occasion, since there are drop pipes in the gap between the two walls, and there are also controls of air conditioning and sound system embedded in it.

The information collected allowed the characterization of the components, in other words, the four layers of the system (five, if included the preparation of the masonry surface), as shown in Fig. 4.

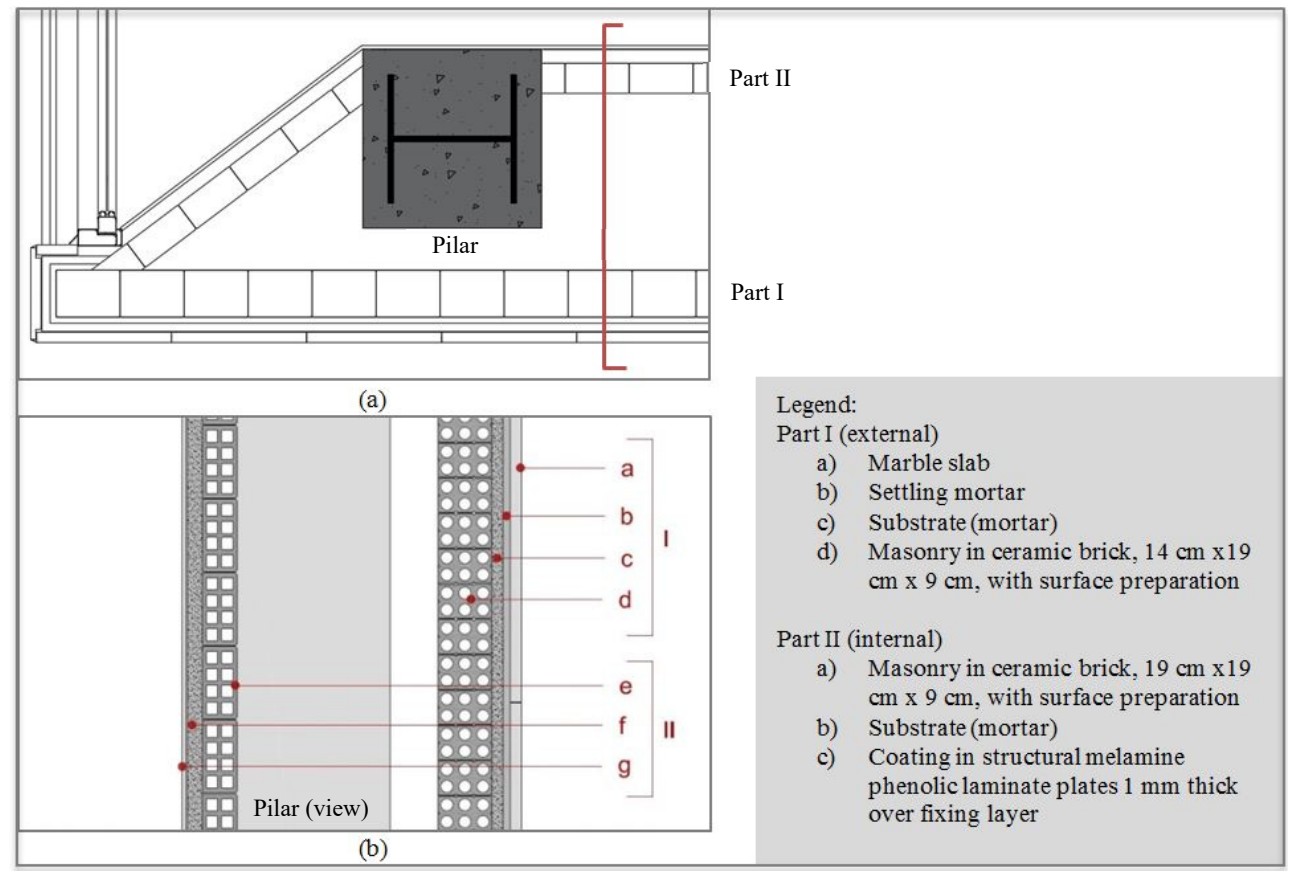

Figure 4: Detail of the marble cladding system of the Brazilian Palace of Congress, South tower. (a) Plant; (b) Vertical section. (Source: Author, 2019.)

When the functionality of a component is affected, the performance of the system is at risk, so it is important to understand not only the features and composition, but also the function that each layer ensures, as listed below.

1. External layer made of slabs of white polished marble called "Branco Italva", $30 \mathrm{~mm}$ thick, with the function of coating and protecting the wall, besides giving the system watertightness;

2. Fixing layer of mortar, $18 \mathrm{~mm}$ thick, made of cement and sand, to give adhesion between the substrate and the marble slabs;

3. Substrate layer ("emboço"), $30 \mathrm{~mm}$ thick, consisting of cement mortar, lime and sand, aimed to regularize the support in order to receive the next layer;

4. Support or base made of 6-hole ceramic brick masonry, $14 \mathrm{~cm}$ x $19 \mathrm{~cm} \times 9 \mathrm{~cm}$, with a surface preparation layer ("chapisco") of mortar (cement and sand), thickness 3 to $5 \mathrm{~mm}$, aimed to promote adherence between the substrate and the support or 
base. This layer acts as a sealing element, responsible for establishing the separation between external and internal environment.

Since the closures of gables consist of a double wall system, only the outer wall was analysed as the base or support of the cladding system. Furthermore, in the studied object, the reinforced concrete beams act as the system base in the interface sections with the façade.

\section{CONCLUSION}

In this paper the physical surveying phase was presented, combining the image capture by UAV to digital photogrammetry, in the scope of the method of analysis of the state of conservation of marble cladding systems in the façades of high-rise modernist buildings.

The proposed procedures were applied to the case study, the façades of the South tower of the Brazilian Palace of Congress in Brasília. The adoption of UAV in the inspection of the palace's gables made it possible to register even the difficult-to-access areas such as the highest floors. In addition, it enabled the photos capture perpendicularly to the plane of the façade, which resulted in images that could be processed by point clouds and the generation of orthoimages that were used to identify and register system damages.

The case study demonstrated that the UAV is an important auxiliary tool in the inspection/monitoring and analysis of the state of conservation of high-rise building façade systems. There are still challenges to be overcome, such as obtaining images with the necessary quality to identify damages such as fissures and cracks, in addition to greater control and stabilization of the equipment, in order to guarantee the achievement of the planned parameters. In this sense, a recommended measure is the adoption of distance sensors attached to the equipment.

The procedures of image capture, digital processing by DSM and vectorization of the orthoimages information allowed the registration of the technical, constructive and conservation state of the system. In a more detailed way, the surveying carried out enabled the identification of the system's component layers, as well as the verification of information from historical documents. With the information that identifies and characterizes the system in study, it is possible to apply the next steps of the method, throughout the additional stages of analysis of state of conservation and elaboration of conservation scenarios. The aim is to contribute to the planning of actions in the scope of conservation and preventive maintenance for the marble cladding system on the Brazilian Palace of Congress façades, with the possibility of transposition to other similar cases.

\section{ACKNOWLEDGEMENTS}

We thank the University community in general and the architects and engineers who work in the House of Representatives, at the Brazilian Palace of Congress, who made the data surveying about the studied system possible.

\section{REFERENCES}

[1] Fisher, S., Edifícios altos no Brasil. Boletim do Instituto de Arquitetura e Urbanismo da Universidade de Brasília, 52(Nov), pp. 30-52, 1991.

[2] Silva, E.G., Os Palácios Originais de Brasília. PhD thesis, Universidade de Brasília, Brasília, 2012.

[3] Costa, L. \& Niemeyer, O., Praça dos três poderes e Palácio do Congresso Nacional. Módulo, 2(9), pp. 14-21, 1958.

[4] Oliveira, M.M., Tecnologia da Conservação e da Restauração, 4th ed., EDUFBA: Salvador, 2011. 
[5] Frascá, M.H.B.O., Estudos Experimentais de Alteração Acelerada em Rochas Graníticas para Revestimento. PhD thesis, Universidade de São Paulo: São Paulo, Brasil, 2003.

[6] Haas, Y.C., Tecnologia de Conservação de Pedras: Uma Sistematização dos Procedimentos para Conservação dos Elementos de Fachada. Thesis, Universidade Federal do Rio de Janeiro, Rio de Janeiro, 2003.

[7] Aires-Barros, L., Alteração e Alterabilidade de Rochas, Instituto Nacional de Investigação Cientifica, Universidade Técnica de Lisboa: Lisboa, 1991.

[8] Melo Júnior, C.M., Metodologia para Geração de Mapas de Danos de Fachadas a partir de Fotografias Obtidas por Veículo Aéreo não Tripulado e Processamento Digital de Imagens. PhD thesis, Universidade de Brasília, Brasília, 2016.

[9] Tondelo, P.G. \& Barth, F., Análise das Manifestações Patológicas em Fachadas por meio de Inspeção com VANT. PARC Pesquisa em Arquitetura e Construção, 10(Feb), e019009, 2019. https://periodicos.sbu.unicamp.br/ojs/index.php/parc/article/view/ 8652817. Accessed on: 12 Apr. 2019.

[10] Córdoba, P.A.F., Levantamento Fotogramétrico de Monumentos Arquitetônicos. Estudo de Caso Palácio Itamaraty - Brasília, DF. Thesis, Universidade de Brasília: Brasília, 2012.

[11] Kim, H., Lee, J., Ahn, E., Cho, S., Shin, M. \& Sim, S., Concrete crack identification using a UAV incorporating hybrid image processing. Sensors, 17(9), 2017. www.mdpi.com/1424-8220/17/9/2052. Accessed on: 28 Apr. 2019.

[12] Ham, Y., Han, K.K., Lin, J.L. \& Golparvar-Far, M., Visual monitoring of civil infrastructure systems via camera-equipped unmanned aerial vehicles (UAVs): A review related to works. Visualization in Engineering, 4(1), 2016.

https://viejournal.springeropen.com/articles/10.1186/s40327-015-0029-z. Accessed on: 28 Apr. 2019.

[13] Groetelaars, N.J., Criação de Modelos BIM a partir de Nuvens de Pontos: Estudo de Métodos e Técnicas para Documentação Arquitetônica. $\mathrm{PhD}$ thesis, Universidade Federal da Bahia, Salvador, 2015.

[14] Costa, L.G.G. \& Amorim, A.L., Geração de ortofotos para produção de mapas de danos. Proceedings of the XIII Congresso da Sociedade Ibero-Americana de Gráfica Digital - SIGRADI, pp. 62-64, 2009.

[15] Instituto de Preservação do Patrimônio Nacional (IPHAN), Anexo 4 - Normativa de mapeamento de danos de materiais lapídeos. Administrative process 01500.000925/2012-24 (not published), Rio de Janeiro, 2012.

[16] International Council on Monuments and Sites - International Scientific Committee for Stone (ICOMOS-ISCS), Illustrated glossary on stone deterioration patterns, 2010.

[17] Ente Italiano di Normazione (UNI), UNI 11182 - Materiali lapidei naturali ed artificiali - Descrizione della forma di alterazione - Termini e definizioni, 2006.

[18] Consiglio Nazionale delle Ricerche - Centrale per il Restauro (CNR-ICR), NORMAL 1/88: Alterazione macroscopiche dei materiali lapidei, Lessico: Roma, 1990.

[19] British Standard Institution (BSI), BS EN 60812: Analysis techniques for system reliability - Procedure for failure mode and effects analysis (FMEA), London, 2006.

[20] American Society of Civil Engineers (ASCE), ASCE/SEI 30-14: Guideline for condition assessment of the building envelope, Virginia, 2014.

[21] American Society for Testing and Materials (ASTM), ASTM E2270: Standard practice for periodic inspection of building, Facades for unsafe conditions, 2014.

[22] Cóias, V., Inspeç̧ões e Ensaios na Reabilitação de Edifícios, Instituto Superior Técnico: Lisboa, 2009. 
150 Structural Studies, Repairs and Maintenance of Heritage Architecture XVI

[23] Tinoco, J.E.L., Mapa de danos: Recomendações básicas. Textos Para Discussão: Série 2 - Gestão de restauro, vol. 43, Centro de Estudos de Conservação Integrada - CECI: Olinda, pp. 1-21, 2009.

[24] Lichtenstein, N.B., Patologia das Construções. Boletim Técnico 06/86, Escola Politécnica da Universidade de São Paulo, Departamento de Engenharia de Construção Civil: São Paulo, 1986.

[25] Brasil - Senado Federal (BR-SF), Contratação de empresa especializada para a prestação de serviços de manutenção de revestimentos de mármore nas fachadas do edifício principal e do Anexo 1 do Senado. Public Notice 036/2017 - Edital do Pregão Eletrônico 036/2017, Brasília, 2017. 